\title{
THE ROLE OF MUSCLE IN OBESITY
}

\author{
BY \\ PAUL KAHN, M.D. (BERLiN), L.R.C.S. \& P. \\ AND \\ NATHANIEL SMITH. \\ (From the Princess Elizabeth of York Hospital for Children, London.)
}

It is generally assumed that the increased weight of obese children is due to an increase of fatty tissue. In the following paper it is proposed to bring forward evidence which is suggestive that such an assumption is unwarranted and that, on the contrary, in the obese child the active muscular tissue shares in no small degree in the production of the abnormal weight.

Schaffer ${ }^{1,2}$ has pointed out that the creatinine output is a good means of estimating the state of muscular development, and it is by a comparison of the creatinine output of normal and obese children that an attempt has been made to determine in how far fat and muscle are responsible for the increased weight. Schaffer states that, assuming the muscles in an adult man to form 50 per cent. of his body weight, $50 \mathrm{mgm}$. creatinine on the average are formed by one $\mathrm{kgm}$. of muscle in twenty-four hours. If this estimate is accepted, and there is no evidence that infantile or adolescent muscle is in this respect different from adult muscle, it is possible to determine from the total daily output of creatinine and the weight of the child what proportion of the body weight is due to active muscular tissue. It is known, however, that the proportion of muscular tissue varies with age $\left(\right.$ Rougichitch $\left.{ }^{3}\right)$ so that it is essential that in any comparative study during childhood only children of approximately the same age should be contrasted.

\section{Material.}

The obese children forming the objects of the present study comprise those who had been referred to hospital during the last two years on account of a too-rapidly increasing weight. In the selection of the controls for comparison with these obese children sex, height and weight was taken into consideration as well as age. Under normal conditions the proportion of fat and muscle is not the same in both boys and girls, hence children of the same sex only are compared. The height of the child also determines the amount of muscular tissue present, and it may be pointed out that in both the obese and control cases this varied within the narrow limits of 96 and 106 per cent. expected height for age. The weight of the control cases varied between 81 and 107 per cent. of the normal standard for the appropriate age. The control children appeared to be in good health at the time of the examination and for the most part were convalescent from such conditions as chorea and subacute rheumatism. 
Methods.

The obese and the normal children studied were confined to bed in hospital and they were given a standard creatine-free diet during the whole course of the investigation. In this way the diet and the urinary output could be controlled. After two preliminary days, the total urine was collected and two successive twenty-four hours' specimens, i.e., those of the third and fourth days, were examined for the creatinine and creatine content according to the method of Folin.

\section{Results.}

Table 1 shows the average creatine output in twenty-four hours, the age, sex, actual weight, estimated amount of muscular tissue and the percentage of this to the body weight, The creatine nitrogen coefficient has been included in this table because it is the usual means of expressing the muscular state of the individual. It does not appear, however, that the creatinine coefficient is particularly suitable for the child, varying as this does with age because of the different proportion of muscle present as the child gets older. This rise of the coefficient from between 5 and 6 in the fifth year to between 7 and 8 in the fourteenth year is evident in the control cases. True, on the average the creatinine coefficient is lower in the obese children and does not show the same rise with age, but there is a considerable overlap, especially among the children under eleven years of age when there is really no difference between the normal and the obese, but what is more important, there would not seem to be any correlation between the coefficient and the degree of obesity as estimated by the relative percentage of increased weight for age.

The figures in table 1 indicate that the increase in body weight of the obese child is not due to fat alone, but that this increase concerns the active tissue as well. Age for age there is a consistent, excessive creatinine output in the obese patients and in some instances this would seem to represent a relatively greater increase in active tissue than would be expected from the increased weight. If, for example, case 2 of the obese group is compared with case 1 of the controls, it is seen that the total weight of the obese child is 158 per cent. of that of the control child, while the muscular tissue of the obese child, as estimated by the creatinine output, is increased to 170 per cent. of that of the control.

The relative increase in total weight and in active muscular tissue is well shown in table 2 where the findings in the obese child are expressed as the percentage of the findings obtained in the case of a control child of the same age and sex.

In every case there is evidence of an increased amount of muscle tissue, in two instances the percentage increase in muscle is in excess of that of the total weight, in four instances the percentage increase in muscle and 
THE ROLE OF MUSCLE IN OBESITY.

TABLE 1.

\begin{tabular}{|c|c|c|c|c|c|c|c|c|}
\hline $\begin{array}{l}\text { Case } \\
\text { no. }\end{array}$ & $\mathrm{S}_{E X}$ & $\begin{array}{c}\text { AGE } \\
\text { IN } \\
\text { YEARS. }\end{array}$ & $\begin{array}{c}\text { WEIGHT } \\
\text { KGM. }\end{array}$ & $\begin{array}{c}\text { Percentage } \\
\text { OF EXPECTED } \\
\text { WEIGHT. }\end{array}$ & $\begin{array}{c}\text { Creatinine } \\
\text { EXCREtion } \\
\text { MGM. }\end{array}$ & \begin{tabular}{|c|} 
CORRESPOND- \\
ING TO \\
MUSCULAR \\
TISSUE \\
KGM.
\end{tabular} & $\begin{array}{c}\text { Percentage } \\
\text { of actual } \\
\text { Body } \\
\text { weight. }\end{array}$ & $\begin{array}{l}\text { Creatinine } \\
\text { Coefficient. }\end{array}$ \\
\hline & & & & Normal & CHILDREN. & & & \\
\hline 1 & $\mathrm{~m}$. & $5_{\frac{1}{12}}^{\frac{1}{2}}$ & $17 \cdot 2$ & 92 & 271 & $5 \cdot 42$ & 31.5 & $5 \cdot 9$ \\
\hline 2 & $\mathrm{~m}$. & $5_{\frac{1}{2}}^{\frac{1}{2}}$ & $17 \cdot 1$ & 91 & 254 & $5 \cdot 08$ & $29 \cdot 7$ & $5 \cdot 5$ \\
\hline 3 & f. & $8 \frac{6}{12}$ & $21 \cdot 1$ & 84.4 & 350 & 7 & $33 \cdot 2$ & $6 \cdot 2$ \\
\hline 4 & f. & 7 & $22 \cdot 6$ & 104 & 438 & $8 \cdot 76$ & $38 \cdot 7$ & $7 \cdot 2$ \\
\hline 5 & $\mathrm{~m}$. & $7 \frac{2}{1}$ & 25 & 101 & 459 & $9 \cdot 18$ & $36 \cdot 7$ & $6 \cdot 8$ \\
\hline 6 & f. & $9 \frac{1}{1} \frac{1}{2}$ & 25.5 & 81 & 444 & $8 \cdot 88$ & $34 \cdot 8$ & 6.5 \\
\hline 7 & f. & $11 \frac{1}{1}^{\frac{0}{2}}$ & $33 \cdot 6$ & 95 & 722 & $14 \cdot 44$ & $42 \cdot 9$ & $8 \cdot 0$ \\
\hline 8 & f. & $11 \frac{1}{1} \frac{1}{2}$ & $32 \cdot 7$ & 89 & 645 & $12 \cdot 9$ & $39 \cdot 4$ & $7 \cdot 3$ \\
\hline 9 & $f_{\text {. }}$ & 12 & $37 \cdot 7$ & 1.02 & 715 & $14 \cdot 3$ & $38 \cdot 4$ & $7 \cdot 0$ \\
\hline 10 & f. & $12 \overline{1}^{\circ}$ & $41 \cdot 2$ & 107 & 646 & $12 \cdot 9$ & $31 \cdot 3$ & $5 \cdot 8$ \\
\hline 11 & f. & $12 \frac{\pi}{12}$ & $37 \cdot 7$ & 95 & 817 & $16 \cdot 34$ & $43 \cdot 3$ & $8 \cdot 1$ \\
\hline 12 & f. & $129 \frac{9}{12}$ & $33 \cdot 9$ & 83 & 625 & $12 \cdot 5$ & 36.9 & $7 \cdot 4$ \\
\hline 13 & $\mathrm{~m}$. & $12^{9} \overline{2}$ & $35 \cdot 7$ & 89 & 655 & $13 \cdot 1$ & $36 \cdot 7$ & $6 \cdot 8$ \\
\hline 14 & f. & 13 & $38 \cdot 2$ & 85 & 778 & $15 \cdot 56$ & $40 \cdot 7$ & $7 \cdot 6$ \\
\hline 15 & f. & $13_{\frac{\pi}{12}}^{\frac{\pi}{2}}$ & $39 \cdot 5$ & 89 & 726 & $14 \cdot 52$ & $39 \cdot 3$ & $6 \cdot 8$ \\
\hline 16 & f. & $13 \frac{1}{1} \frac{0}{2}$ & $38 \cdot 2$ & $\begin{array}{l}91 \\
\text { OBESE }\end{array}$ & $\begin{array}{c}790 \\
\text { CHILDREN. }\end{array}$ & $15 \cdot 8$ & 41.5 & $7 \cdot 7$ \\
\hline 1 & $\mathrm{~m}$. & $4 \frac{8}{12}$ & $30 \cdot 4$ & 170 & 365 & $7 \cdot 3$ & 20 & 4.4 \\
\hline 2 & f. & $5_{\frac{1}{2}}^{\frac{3}{2}}$ & $27 \cdot 3$ & 150 & 436 & $9 \cdot 26$ & $33 \cdot 9$ & $5 \cdot 9$ \\
\hline 3 & $\mathrm{~m}$ & $8 \frac{5}{12}$ & 34.5 & 121 & 653 & $13 \cdot 06$ & $37 \cdot 8$ & $7 \cdot 0$ \\
\hline 4 & f. & 9 & $43 \cdot 2$ & 170 & 717 & $14 \cdot 34$ & $33 \cdot 2$ & $6 \cdot 2$ \\
\hline 5 & f. & $12 \frac{9}{12}$ & 64 & 169 & 927 & 18.54 & 29 & $5 \cdot 4$ \\
\hline 6 & f. & $122^{6}:-5$ & 65 & 165 & 1,006 & $20 \cdot 12$ & $30 \cdot 9$ & $5 \cdot 9$ \\
\hline 7 & f. & $12{ }_{19}^{\circ} \frac{1}{2}$ & 51.4 & 131 & 816 & $16 \cdot 32$ & $31 \cdot 7$ & $5 \cdot 8$ \\
\hline 8 & f. & $122_{\frac{1}{2}}^{6}$ & 51 & 129 & 831 & $16 \cdot 62$ & $32 \cdot 6$ & $6 \cdot 1$ \\
\hline 9 & f. & $1 \cdot 27$ & $73 \cdot 1$ & 187 & 923 & $18 \cdot 46$ & $25 \cdot 3$ & 4.7 \\
\hline 10 & f. & $12 \frac{1}{1} \frac{0}{2}$ & $64 \cdot 8$ & 154 & 951 & $19 \cdot 02$ & $29 \cdot 3$ & $5 \cdot 4$ \\
\hline 11 & f. & $12 \frac{1}{1} \frac{0}{2}$ & 77 & 190 & 1,253 & $25 \cdot 06$ & 32.5 & $6 \cdot 1$ \\
\hline 12 & f. & 13 & 77 & 173 & 1,252 & $25 \cdot 04$ & 32.5 & $6 \cdot 1$ \\
\hline 13 & f. & $13_{\frac{8}{1}}^{\frac{8}{2}}$ & 77 & 169 & 1,231 & $24 \cdot 62$ & 31.9 & $6 \cdot 0$ \\
\hline 14 & f. & $13 T^{2}=$ & $55 \cdot 9$ & 131 & 925 & $18 \cdot 5$ & 33 & 6.2 \\
\hline
\end{tabular}


in body weight are practically identical and in six the percentage increase in body weight is in excess of that of the muscle. Yet in all but three of the latter, the difference between the increase in total weight and in muscle does not exceed 30 per cent. In only one case, no. 9 of the obese group, is this difference really great. This child suffered from an old septic

\begin{tabular}{|c|c|c|c|c|c|c|}
\hline $\begin{array}{l}\text { CASE } \\
\text { No. }\end{array}$ & $\begin{array}{c}\text { OBRSE } \\
\text { OR } \\
\text { NoRMAI }\end{array}$ & $\begin{array}{c}\text { WhigitT } \\
\text { KGM. }\end{array}$ & $\mid \begin{array}{c}\text { OVER WEIGHT OF } \\
\text { OBESE OYER } \\
\text { NORMALCHIIDRLN } \\
\text { PER CENT. }\end{array}$ & $\begin{array}{l}\text { Active } \\
\text { MUSCULAR } \\
\text { TISSUE } \\
\text { KGM. }\end{array}$ & $\begin{array}{c}\text { OVERWEIGHT OF } \\
\text { MCSCULAR TISSUI: } \\
\text { OF OBESE OVER } \\
\text { THAT OF NORHA } \\
\text { CHIIDREN } \\
\text { P'ER CENT. }\end{array}$ & $\begin{array}{l} \\
\text { CREATINiNe } \\
\text { COEFFicient }\end{array}$ \\
\hline $\begin{array}{l}2 \\
1\end{array}$ & $\begin{array}{l}o b . \\
n .\end{array}$ & $\left.\begin{array}{l}27 \cdot 3 \\
17 \cdot 2\end{array}\right\}$ & 1.58 & $\left.\begin{array}{l}9 \cdot 26 \\
5 \cdot 42\end{array}\right\}$ & 170 & $\begin{array}{l}5 \cdot 9 \\
5 \cdot 9\end{array}$ \\
\hline $\begin{array}{l}3 \\
3\end{array}$ & $\begin{array}{l}o b . \\
n .\end{array}$ & $\left.\begin{array}{l}34 \cdot 5 \\
21 \cdot 1\end{array}\right\}$ & 163 & $\left.\begin{array}{r}13 \cdot 06 \\
7 \cdot 00\end{array}\right\}$ & 187 & $\begin{array}{l}7 \\
6 \cdot 2\end{array}$ \\
\hline $\begin{array}{l}4 \\
6\end{array}$ & $\begin{array}{l}o b . \\
n .\end{array}$ & $\left.\begin{array}{l}43 \cdot 2 \\
25 \cdot 5\end{array}\right\}$ & 169 & $\left.\begin{array}{r}14 \cdot 34 \\
8 \cdot 85\end{array}\right\}$ & 162 & $\begin{array}{l}6 \cdot 2 \\
6 \cdot \tilde{5}\end{array}$ \\
\hline $\begin{array}{l}\tilde{5} \\
9\end{array}$ & $\begin{array}{l}o b . \\
n .\end{array}$ & $\begin{array}{l}64 \\
37 \cdot 7\end{array}$ & 170 & $\left.\begin{array}{l}18 \cdot 54 \\
14 \cdot 3\end{array}\right\}$ & 130 & $\begin{array}{l}5 \cdot 4 \\
7 \cdot 0\end{array}$ \\
\hline $\begin{array}{r}6 \\
10\end{array}$ & $\begin{array}{l}o b . \\
n .\end{array}$ & $\begin{array}{l}65 \\
41 \cdot 2\end{array}$ & 160 & $\left.\begin{array}{l}20 \cdot 12 \\
12 \cdot 9\end{array}\right\}$ & 157 & $\begin{array}{l}5 \cdot 9 \\
5 \cdot 8\end{array}$ \\
\hline $\begin{array}{r}7 \\
10\end{array}$ & $\begin{array}{l}o b . \\
n .\end{array}$ & $\left.\begin{array}{l}51 \cdot 4 \\
41 \cdot 2\end{array}\right\}$ & 124 & $\left.\begin{array}{l}16.32 \\
12.9\end{array}\right\}$ & 126 & $\begin{array}{l}5 \cdot 8 \\
5 \cdot 8\end{array}$ \\
\hline $\begin{array}{r}8 \\
10\end{array}$ & $\begin{array}{l}o b . \\
n .\end{array}$ & $\begin{array}{l}51 \\
41 \cdot 2\end{array}$ & 123 & $\left.\begin{array}{l}16 \cdot 62 \\
12 \cdot 9\end{array}\right\}$ & 128 & $\begin{array}{l}6 \cdot 1 \\
5 \cdot 8\end{array}$ \\
\hline $\begin{array}{r}9 \\
11\end{array}$ & $\begin{array}{l}o b . \\
n .\end{array}$ & $\begin{array}{l}73 \cdot 1 \\
37 \cdot 7\end{array}$ & 193 & $\left.\begin{array}{l}18 \cdot 46 \\
16 \cdot 34\end{array}\right\}$ & 113 & $\begin{array}{l}4 \cdot 7 \\
8 \cdot 1\end{array}$ \\
\hline $\begin{array}{l}10 \\
11\end{array}$ & $\begin{array}{l}o b . \\
n .\end{array}$ & $\begin{array}{l}64 \cdot 8 \\
33 \cdot 9\end{array}$ & 191 & $\left.\begin{array}{l}19 \cdot 02 \\
12.5\end{array}\right\}$ & 152 & $\begin{array}{l}5 \cdot 4 \\
7 \cdot 4\end{array}$ \\
\hline $\begin{array}{l}11 \\
13\end{array}$ & $\begin{array}{l}o b . \\
n .\end{array}$ & $\begin{array}{l}77 \\
35 \cdot 7\end{array}$ & 212 & $\left.\begin{array}{l}25 \cdot 04 \\
13 \cdot 1\end{array}\right\}$ & 190 & $\begin{array}{l}6 \cdot 1 \\
6 \cdot 8\end{array}$ \\
\hline $\begin{array}{l}12 \\
14\end{array}$ & $\begin{array}{l}o b . \\
n .\end{array}$ & $\begin{array}{l}77 \\
38 \cdot 2\end{array}$ & 201 & $\left.\begin{array}{l}25 \cdot 04 \\
15 \cdot 56\end{array}\right\}$ & 161 & $\begin{array}{l}6 \cdot 1 \\
7 \cdot 6\end{array}$ \\
\hline $\begin{array}{l}13 \\
15\end{array}$ & $\begin{array}{l}o b . \\
n .\end{array}$ & $\begin{array}{l}77 \\
39 \cdot 5\end{array}$ & 195 & $\left.\begin{array}{l}24 \cdot 62 \\
14 \cdot 52\end{array}\right\}$ & 169 & $\begin{array}{l}6 \cdot 0 \\
6 \cdot 8\end{array}$ \\
\hline $\begin{array}{l}14 \\
16\end{array}$ & $\begin{array}{l}o b . \\
n .\end{array}$ & $\begin{array}{l}55 \cdot 9 \\
38 \cdot 2\end{array}$ & 146 & $\begin{array}{l}18 \cdot 5 \\
15 \cdot 8\end{array}$ & 117 & $6 \cdot 2$ \\
\hline
\end{tabular}

arthritis of the right hip joint with ankylosis and atrophy of the right leg and an underdevelopment of the muscles of the left leg; case no. 11 of the control series, with whom she is compared, was a particularly muscular child with the highest creatinine output of the normal series. Nevertheless the child showed an increase of muscular tissue of 13 per cent. compared with a well-developed control. The relation between the increase in muscle 
and increase in weight is shown graphically in the accompanying chart and reveals in a striking fashion the parallelism which exists between them.

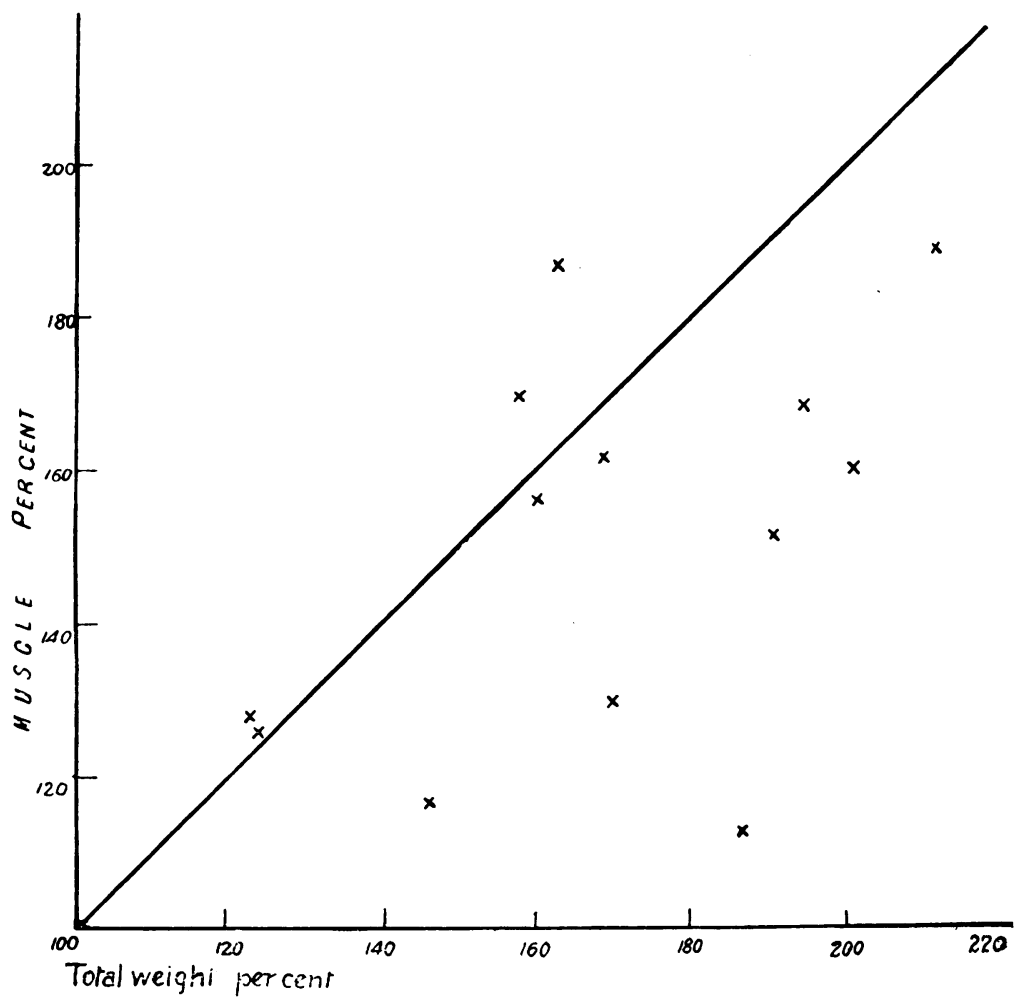

CharT.-Showing relation between the body weight and muscle weight in the obese children. On the ordinate are given the body weight and on the abscissa the muscle weight as percentage of normal. The chart shows the findings from table 2 graphically.

\section{Creatine-creatinine tolerance.}

It might of course be argued that the creatine-creatinine metabolism is modified in the obese state and hence comparisons such as the above are unjustified. To explore this possibility a suggestion made by Prof. Andrew Hunter was adopted to test the tolerance of both types of children against ingested creatine and creatinine. This was carried out in the following manner.

After the children had been kept on a creatine-free diet and their average basal excretion of creatinine and creatine established, they were given in the first place $500 \mathrm{mgm}$. of creatinine by mouth, the urine being collected during three successive days and the excess of creatinine over the basal amount determined. When the basal conditions were once more reached the children were given $500 \mathrm{mgm}$. of creatine, the urine again collected on the following three days and the output of creatinine and creatine ascertained. Details of the findings are given in table 3. 


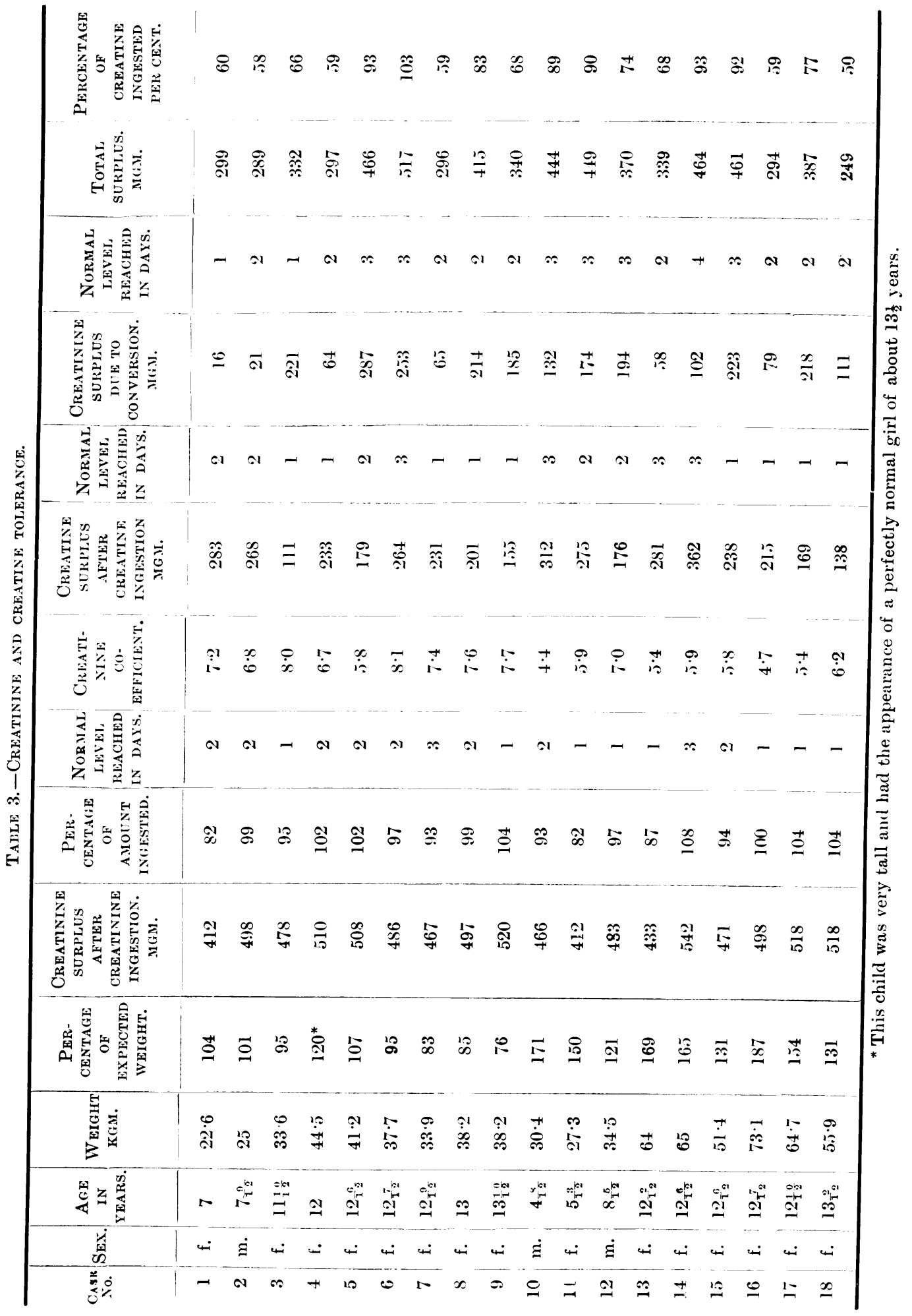


From the above findings it would appear that there is no tolerance of either the obese or normal child to creatinine. Only three of the eighteen children (obese and normal combined) excreted less than 90 per cent. of the ingested creatinine, and in these particular cases the poor excretion may be attributed to defective absorption. Fight of the children had excreted the ingested creatinine within twenty-four hours, eight reached the normal level within forty-eight hours, and in the remaining two (one normal and one obese) the surplus excretion continued for three days.

In the case of the ingested creatine, on the other hand, the excretion was more complex. First of all there resulted an immediate increase in the basal output of creatine. The total amount excreted varied within wide limits, but it did not seem to be influenced by sex; age or the weight of the child. At the same time, or on the following day, the creatinine excretion also rose above the average basal level, due apparently to a conversion of some of the creatine into creatinine. The amount thus converted also varied within wide limits and, similarly, did not seem to have any relationship to the sex, age or weight of the child.

These findings do not reveal any difference in the creatine-creatinine tolerance nor in the creatine-creatinine metabolism of the obese and normal child, and hence the comparison of the creatinine output of children of the same age would seem to be justified.

\section{Conclusions.}

1. The creatinine and creatine metabolism is the same in the obese and in the normal child.

2. There is no tolerance of the normal or obese child for creatinine, fully 90 per cent. of the amount ingested by the mouth being excreted in the urine.

3. The daily output of creatinine of the obese child is invariably above that of the normal child of the same age.

4. In the majority of examples of obesity studied (7 out of 13) the percentage increase of creatinine excretion is commensurate with the percentage increase of the weight of the child.

5. In the so-called obese child the increase in weight is as a rule due as much to increase of muscle as to increase of fat. 
We wish to express our gratitude to Dr. Leonard Findlay for his suggestions and his kind help.

\section{REFERENGES.}

1. Schaffer, P. A., Am. J. Physiol., Baltimore, 1908, XXIII, 1.

2. Schaffer, P. A., J. Biol. Chem., Baltimore, 1914, XVIII, 525.

3. Rougichitch, O. S., Arch. Dis. Childh., London, 1926, II, 348. 